\title{
The effects of bush control methods on encroaching woody plants in terms of die- off and survival in Borana rangelands, southern Ethiopia
}

\author{
Malicha Loje Hare ${ }^{1,2,3}$, Xinwen X $\mathbf{u}^{1,2}$, Yongdong Wang ${ }^{1,2^{*}}$ and Abule Ibro Gedda ${ }^{4}$
}

\begin{abstract}
A study on the effect of bush control methods on encroaching woody species, namely Acacia drepanolobium, Acacia mellifera and Acacia reficiens was conducted for a 2 years' time. A 3 ha of land was divided into two plots. Each replication with an area of $300 \mathrm{~m} \times 50 \mathrm{~m}$ was again sub-divided into six plots (each $50 \mathrm{~m} \times 50 \mathrm{~m}$ ) to accommodate six treatments. Bush control treatments were assigned randomly to the plots and replicated two times across sites of similar topography. During the post-treatment period, responses of woody species to different treatments in terms of mortality and coppicing were monitored. Data was analysed using R software and Tukey's studentized range tests for comparisons of means. The applied treatments significantly influenced $(P<0.05)$ encroaching woody species. The finding showed that five out of the six bush control treatments greatly promoted woody mortality, however with species-specific differences. The stem-burning, tree cutting with fire-browse combination, cutting and fire, cutting and browsing, and cutting treatments greatly increased species mortality compared to the control treatment. Responses due to treatment effect also varied significantly $(P<0.05)$ among encroaching woody species. Accordingly, mortality was higher in A. reficiens than in the other two species, indicating that $A$. reficiens is greatly susceptible to the applied treatments. The significant finding was that woody species exhibited greater mortality in response to selective cutting/thinning and post-management techniques. Post-thinning management measures would sustain savanna ecology, if implemented at certain intervals.
\end{abstract}

Keywords: Treatments, Woody species, Mortality, Coppicing, Borana

\section{Introduction}

Over the past century, an increase in cover, density and biomass of indigenous woody plant species (Van Auken 2009) referred to as 'bush encroachment' has been reported worldwide (Eldridge et al. 2011), and has been particularly visible in African savannas (Sankaran et al. 2005). The encroachment of woody plants has been

\footnotetext{
* Correspondence: wangyd@ms.xjb.ac.cn

${ }^{1}$ State Key Laboratory of Desert and Oasis Ecology, Xinjiang Institute of Ecology and Geography, Chinese Academy of Science, Urumqi P.O. 830011, China

${ }^{2}$ National Engineering Technology Research Centre for Desert-Oasis Ecological Construction, Beijing 100049, China

Full list of author information is available at the end of the article
}

attributed to the replacement of indigenous herbivores by domestic grazing animals and the intense utilization of the herbaceous vegetation by domestic livestock (Britz and Ward 2007a, 2007b). Herbaceous species compete with woody plants for resources (e.g. water) in the topsoil, and reduction of herbaceous growth by grazing reduces the competitive vigour of herbaceous species, potentially enhancing woody plant growth (Hoffman and Ashwell 2001; Riginos et al. 2009). Furthermore, heavy grazing results in reduced fuel loads leading to less frequent and low-intensity fire, which reduces the effectiveness of fire in the control of woody vegetation (Hoffman and Ashwell 2001; Riginos and Young 2007). Intense 
and frequent fires often kill woody plants, thus preventing the establishment of a continuous canopy cover (Smit et al. 2010; Higgins et al. 2007). When fires are less intense, woody plant saplings can grow and escape the fire flame zone and become fire-resistant (Brown and Archer 1999). A trend towards an increase in woody encroachment also suggests that increases in atmospheric $\mathrm{CO}_{2}$ and long-term climate variability might contribute to woody encroachment in savanna ecosystems (Kulmatiski and Beard 2013; D'Odorico et al. 2010). In general, local climate and climate change in combination with grazing effect and suppression of fire have been reported as possible drivers of bush encroachment (Ward et al. 2000; Oba et al. 2000; Ayana and Oba 2008b).

Bush encroachment can cause biome shifts from open savannas to closed woodlands (Eldridge et al. 2011), altering the functions and biodiversity of the original savanna which thereby reduces the productivity and economic benefits from rangelands (Buitenwerf et al. 2012). Woody vegetation reduces cover and yields of the herbaceous layer through increasing the competition for available water and nutrients and reducing sunlight that should reach to the grass layer (Kahi et al. 2009; Teshome et al. 2012) and hence leading to reduced carrying capacity for livestock (Ward 2005).

The threat to the pastoral economy by bush encroachment is often the main reason for the control of bush encroachment (Olson and Whitson 2002). Bush control methods shift the rangeland vegetation from dominance by woody vegetation to dominance by herbaceous vegetation. Bush encroachment control is aimed at creating a suitable habitat for grazers while reducing the ability of invasive plants to exhibit their survival mechanisms. Thus, forage production of herbaceous vegetation increases with the reduction of woody species (Lesoli et al. 2013).

The Borana rangelands of southern Ethiopia, once dominated by an open, mixed savanna of perennial grasses and scattered woody plants, are now covered by dense stands of thorn-bush (Coppock et al. 2008). The study by Dalle et al. (2006) has estimated the progression of bush cover to $52 \%$ and Ayana (2007) reported $83 \%$ of the Borana rangelands are threatened by encroachment of bushes and unpalatable forbs, while (Abule E: Rangeland suitability evaluation for livestock production in Laga-Wata/Laga Sura, Dawa and rift valley basins of the Borana Zone of Oromia, Southern Ethiopia, unpublished) revealed more than $63 \%$ bush cover in the Borana rangelands. Bush cover reached a peak in 2007 (83\%) and declined (63\%) in 2009 (Ayana 2007 and (Abule E: Rangeland suitability evaluation for livestock production in Laga-Wata/Laga Sura, Dawa and rift valley basins of the Borana Zone of Oromia, Southern Ethiopia, unpublished) above). The reason behind the decline could be self-thinning due to competition for moisture and light. Acacia species such as Acacia drepanolobium, Acacia reficiens and Acacia mellifera are identified as the most encroaching species (Oba 1998; Keba 2013). Rangeland management systems in the area, including fire, have reduced woody species proliferation and may have maintained open rangelands for centuries (Ayana and Oba 2008a). However, overgrazing and the complete suppression of fire has increased woody encroachment in the Borana rangelands (Ayana and Oba 2008b).

Similarly, rainfall might have played the major role in the variation of vegetation dynamics in semi-arid Borana lowlands. According to the meteorological data described under the 'Methods and materials' section, the mean annual rainfall of the study district (1998-2019) varied significantly $(P<0.01)$ across years. In addition, the mean annual rainfall $(\mathrm{mm})$ recorded during the study years, i.e. 2018 and 2019, showed an increasing $(P<0.05)$ trend when compared against the region's long-term average. Keba (2013) suggested high rainfall as one of the reasons for high woody density in the Borana rangelands, after observing higher seedling density in higher rainfall range sites than in the corresponding sites which received a lower amount of rainfall. Ayana and Oba (2008b) also concluded that shift in vegetation cover from an open savanna to bush encroached is also likely controlled by stochastic rainfall than by overgrazing alone.

It is therefore important to note that land-use practice alone is not the driving force of bush encroachment in the region. Analyses of woody cover patterns across Africa suggest that maximum woody cover in savannas receiving an annual precipitation of less than $650 \mathrm{~mm}$ is constrained by rainfall (Sankaran et al. 2005). These dry areas are stable systems in which water constrains woody cover, permitting tree-grass coexistence. In contrast, areas receiving more than $650 \mathrm{~mm}$ annual precipitation are unstable systems that require fire and herbivory in order to maintain a savanna system; these wet areas would otherwise shift to a woodland system (Sankaran et al. 2005).

Soil type and nutrient availability may also influence plant growth and species composition. Texture is an important soil property because it greatly modifies the water intake rates, water storage in the soil, amount of aeration and soil fertility (Miller and Donahue 1995). The rangeland soils of East Africa including the soils of the current study area are regarded as having low fertility, probably due to low inherent fertility of the parent materials (Pratt and Gwynne 1977). The soil types of the region described under the 'Study area' section are dominated by sandy clay loam textural classes. The sandy soils alone cover $53 \%$ of the area, and other types of clay loam soils occupied the balance. Texture influences 
plant growth by its direct effect on soil aeration, water infiltration, nutrient retention capacity and erodibility. In general, infiltration and permeability are rapid in sandy soils, very slow in clay soils and intermediate in loam soils (Coppock 1994; Miller and Donahue 1995). In the semi-arid Borana lowlands, woody plants are generally adapted to sandy soils, while silt and clay soils were dominated by herbaceous plants (Keba 2013). According to the same author, the reason for the high density of woody plants in sandy soils might be due to leaching of soil nutrient and run-off that could accelerate the $\mathrm{pH}$ of a soil such that herbaceous plants could not tolerate. Most encroaching acacia species are deep-rooted trees. The study by Tamene (1990) revealed that the tap roots of $A$. brevispica and $A$. drepanolobium can extend up to 5-6 m. Thus, the widespread abundance of woody species in the study area might be associated with their ability to access available soil water and nutrient at deep soil layers. The persisting ability of woody vegetation due to the nature of their root system which grants them exclusive access to water occurring in deeper soil layers has been reported elsewhere (Ward et al. 2013; O'Connor et al. 2014). This leads to woody plants becoming the superior competitor of the vegetation layers (Ward 2005). The herbaceous species are known to be superior competitors for soil moisture occurring at shallow depths in an arid savanna (Ward et al. 2013).

In general, bushes are transforming open grazing lands into impenetrable thicket-forming trees and suppressing desirable grasses through competition, thus becoming unsuitable for grazing. This is because once adult woody plants become well-established, they can out-compete grasses for moisture and light (Solomon and Mblambo 2010). Less grass means fewer and less productive cattle to support pastoral livelihoods. This translates into less milk and meat produced per cow which is the traditional mainstay of pastoral diets (Megersa et al. 2014; Forrest et al. 2015).

Pastoral communities in the Borana area have been seeking ways to mitigate the pervasive effects of overgrazing (Tache and Oba 2010; Forrest et al. 2015). One strategy is the clearing of bush-encroached sites to promote grass growth to provide more forage to certain classes of livestock (Forrest et al. 2015). However, bush clearing has shown to be unsuccessful for long-term woody encroachment control, as the reductions in woody plant cover achieved are usually temporary, and woody plant abundance typically recovers remarkably in the decade following treatment application (Grant et al. 1999; Ayana and Oba 2009). Ayana and Oba (2008b) also concluded that hand removal of bushy plants is among multiple drivers of bush encroachment in the Borana rangelands.
In an attempt to restore bush-encroached grasslands, researchers (Tainton 1999; Smit 2005) have indicated two alternative approaches to the problem of increasing tree density in the savanna that needs to be assessed before any woody plant control programme is embarked on. One approach is to adapt the livestock system to the existing vegetation, and if tree densities are high and woody plants are palatable, browsers should form an important component of livestock system. The second approach is to modify the vegetation to suit a specific livestock system and particularly a system based on grazing animals, especially where the vegetation has been greatly modified by past management practices. Where this option is adopted in areas with a high tree density, the first operation has to be often the drastic one of thinning down to some predetermined density, after which a post-thinning management programme will be needed to keep the area open.

In addition, control aids applied include tree cutting (Smit 2005), fire (DiTomaso et al. 2006), and the use of browsing animals (Smit et al. 1999; De Klerk 2004) and combinations thereof. Most often, a single method is not always effective to achieve sustainable control of bush encroachment. Thus, integrated approaches are warranted to restore rangelands degraded by bush encroachment by combining more than one method (DiTomaso et al. 2006). Mechanical cutting suppresses the growth of trees at least in the short term (Clark and Wilson 2001), and it has been shown (Smit 2005; Kahumba 2010) that cutting off bushes at ground level will temporarily open the canopy without reducing bush density (i.e. trees/ha). Past studies (Lubbe L: Notes on trees and shrubs in arid and semi-arid regions, unpublished; Ayana and Oba 2009) have reported that most acacias have the ability to coppice and, if allowed to re-grow, many bush species will form an even denser thicket after slashing than before.

Fire suppresses bush growth by killing and reducing the abundance of encroaching woody species (Ruthven et al. 2003; Ansley and Castellano 2006). Control of bush encroachment by fire has a variable success rate. The denser the bush infestation, the less grass and other fuels will be available under the bush (Kahumba 2010). Thus, range fires alone are less effective in killing woody components (Trollope 1999a, 1999b), but can be used profitably in association with other methods of control to modify the structure of the woody layer (Van Rooyen 2002; Pienaar 2006). Stem-burning, in which a low-intensity fire burns for an extended period around the stem of the woody plant, is effective in the selective control of individual trees (Smit et al. 1999; Pienaar 2008). However, fire can produce physical, chemical and biological alterations in soil properties (Úbeda and Outeiro 
2009). The changes to the soil produced by controlled fire are in most cases only transient.

Browsing animals such as goats are well suited to controlling woody plants because the intensity and frequency with which they utilize the browse can be controlled. Goats used in a system which allows coppice growth to be used frequently and severely will impact on woody plants (Smit 1999; Pienaar 2006). Goats can be used together with mechanical methods in the initial thinning in a bush control programme (Trollope 1974; Smit 1999; Zimmermann et al. 2003). Earlier studies (Teague 1989a, 1989b) have reported browsing of plots stocking with 1.2 to 2.2 Boer goats per hectare $\left(\mathrm{ha}^{-1}\right)$ depending on annual estimates of available browse for commercial livestock farmers who wish to increase grass production by reducing bush.

Understanding the effects of bush encroachment control methods and the respective responses on woody species is important for the management of savanna ecosystems (Masters and Sheley 2001; Ansley and Castellano 2006; Ayana and Oba 2009), whereas past studies reported the effect of single cutting/clearing operations. Nevertheless, the effect of thinning and post-management measures on woody plants has not been studied. Post-thinning management techniques might help to re-establish the savanna in the Borana ecology. Identifying responses of individual species to post-thinning management measures may enable practitioners to design appropriate management strategies for a bush encroachment control programme. Therefore, the objectives of the study were (i) to investigate responses of selected woody species to the postthinning management measures of the selectively thinned savanna in terms of mortality and coppicing and (ii) to evaluate and compare the efficacy of methods in controlling thickening of woody plants.

\section{Study area}

The study was undertaken in the Borana rangelands of Ethiopia. The Borana rangelands are located in the southern part of the Ethiopian lowlands, and cover a total land of $95,000 \mathrm{~km}^{2}$ (Kamara et al. 2002). The area extends from 4 to $6^{\circ} \mathrm{N}$ latitude and 36 to $42^{\circ} \mathrm{E}$ longitudes, and the altitude ranges from 1000 metres above sea level (m.a.s.l) to 1700 m.a.s.l (Coppock 1994). The area has a semi-arid climate with annual rainfall ranging from 450 to $700 \mathrm{~mm}$ (Helland 1980). Rainfall is bimodal with $60 \%$ of the annual precipitation occuring between March and May and the remaining between September and November. The mean annual temperature varies from 19 to $24{ }^{\circ} \mathrm{C}$. The geology of the area is dominated by $40 \%$ quaternary deposits, $38 \%$ basement complex formation and 20\% volcanic. The soil types of the region comprise $53 \%$ sand, $30 \%$ clay and $17 \%$ silt, which is sandy clay loam. The Borana plateau is dominated by a
Savanna type of vegetation containing a mixture of perennial herbaceous and woody plants (Coppock 1994) (Fig. 1).

The study area has an estimated population of 503,877 (Central Statistical Authority (CSA) 2017). The Borana and Gabra Oromos are among the pastoral groups living in the zone. Livestock production is an important component of the local economy. The populations of cattle, goats, sheep, donkeys, horses, mules and camels are estimated to be $1,482,053 ; 1,179,645 ; 637,632 ; 68,799 ; 2222$; 5525 and 185,382, respectively (Central Statistical Authority (CSA) 2017). The communal and seasonal enclosures and ranches are grazed by cattle, sheep, goats and camels. The grazing capacity of the study region is 4.49 ha/TLU (Keba 2013). The study area has a huge potential for tourism development. Crater lakes (Boqe), wildlife and birds (endemic), forests, mountains and cultural centres (Gumi-Gayo) are among the well-known tourist attractions of the area. The Bos indicus Borana breed which are the most important cattle of the country, also originated in this region (Aynalem et al. 2011).

\section{Materials and methods \\ Experimental procedures \\ Selection and description of the study site}

Representative and major grazing areas in Yabalo pastoral district, including both communal and ranches with different tree species, were identified through participatory reconnaissance surveys by a committee composed of elder pastoralists and experts in pastoral offices (i.e., zonal and district). Accordingly, one grazing ranch (Dida-Tuyura) site and one communal grazing area (Har-Weyu), each with widely abundant mature trees of Acacia drepanolobium, Acacia mellifera and Acacia reficiens, was selected for the study. The selection of the three tree species was based on their abundance and socio-ecological importance (Coppock 1994; Solomon and Mblambo 2010). Topography was taken into consideration when selecting the sites. All the grazing sites fell within an altitude range of 1200 to 1350 m.a.s.l, with a similar landscape.

\section{Climatic characteristics}

Rainfall data was obtained from Yabalo town, which is the nearest meteorological station. Mean monthly rainfall ranged from 4.6 to $130.6 \mathrm{~mm}$ with peaks in April and October demonstrating a bimodal type of rainfall. The main wet season is from March to May, and the shorter wet season is from September to November (Fig. 2).

Over the years, the total annual rainfall ranged from 372.1 to $1349.9 \mathrm{~mm}$. Annual rainfalls recorded during the study years were $960.3 \mathrm{~mm}$ and $1349.9 \mathrm{~mm}$ in 2018 and 2019, respectively. The variation in annual rainfalls is significant $(P<0.01)$ with the peak in 2019 , which is 


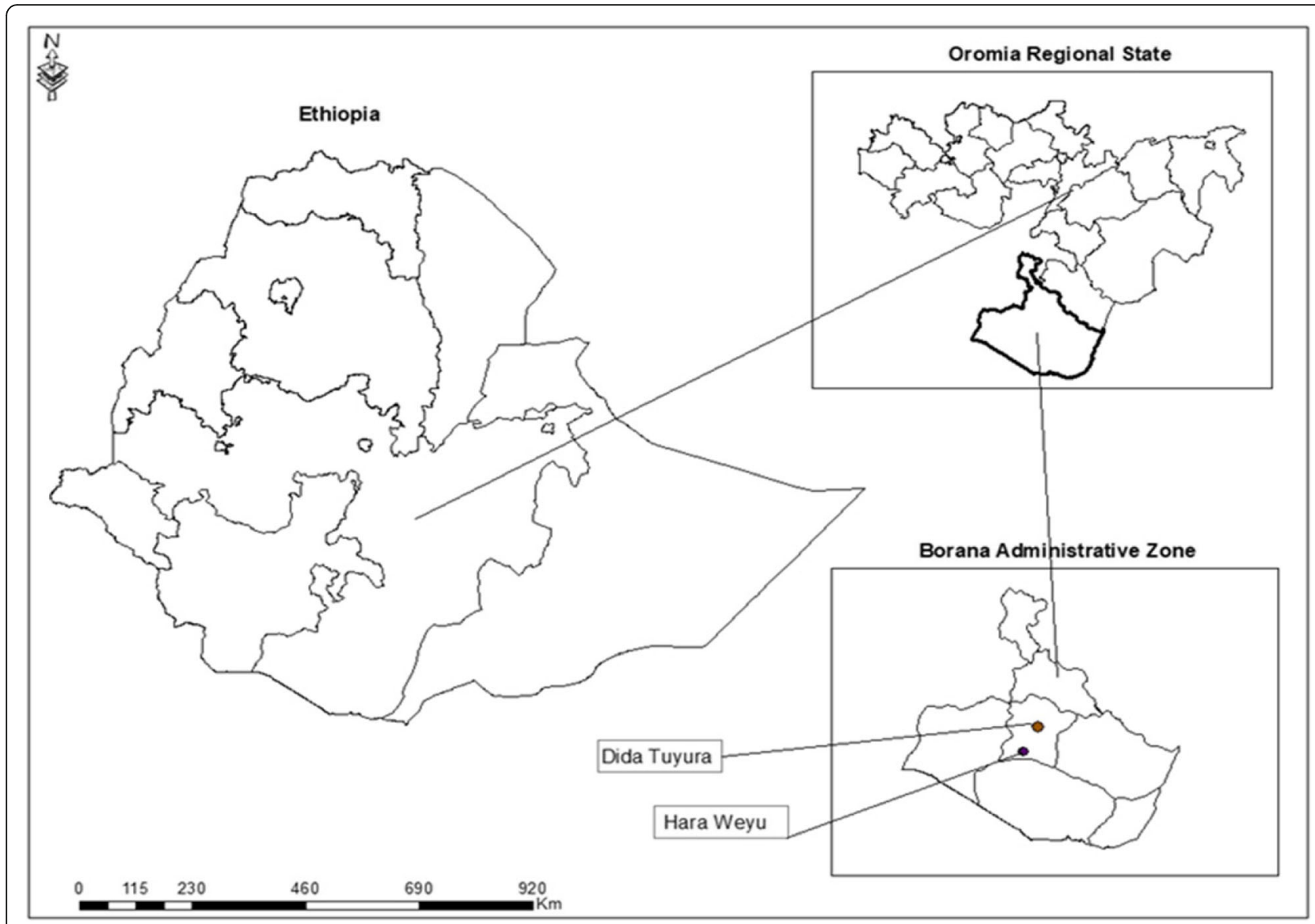

Fig. 1 Map of Ethiopia showing the study area

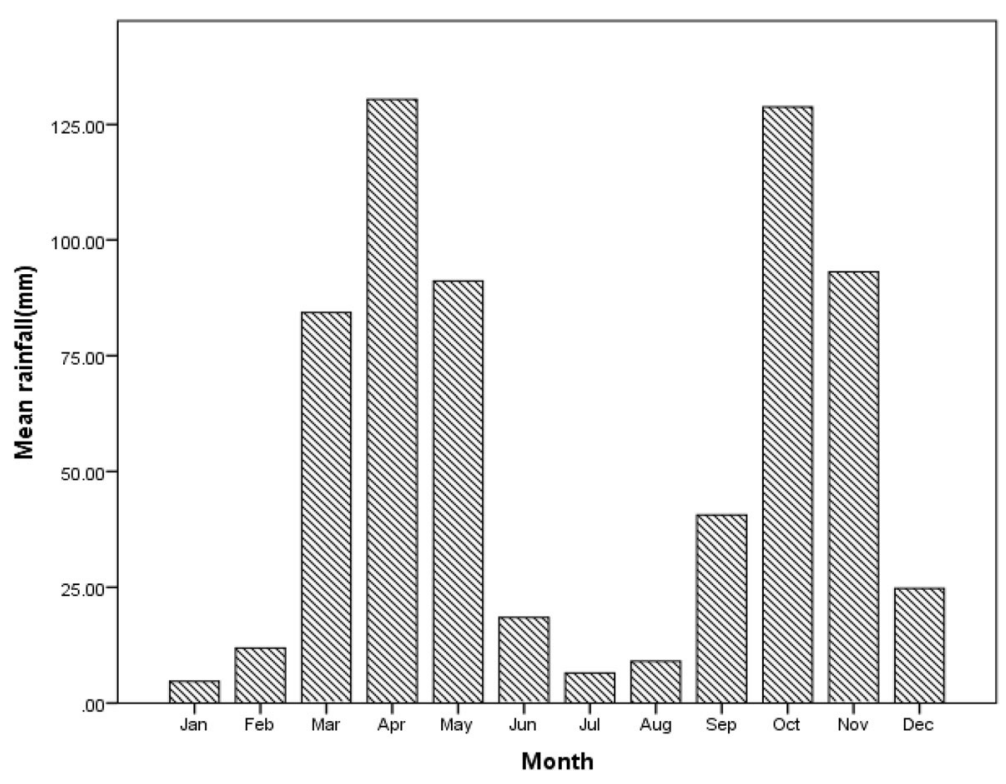

Fig. 2 Mean monthly rainfalls over a period of 22 years in the study district 


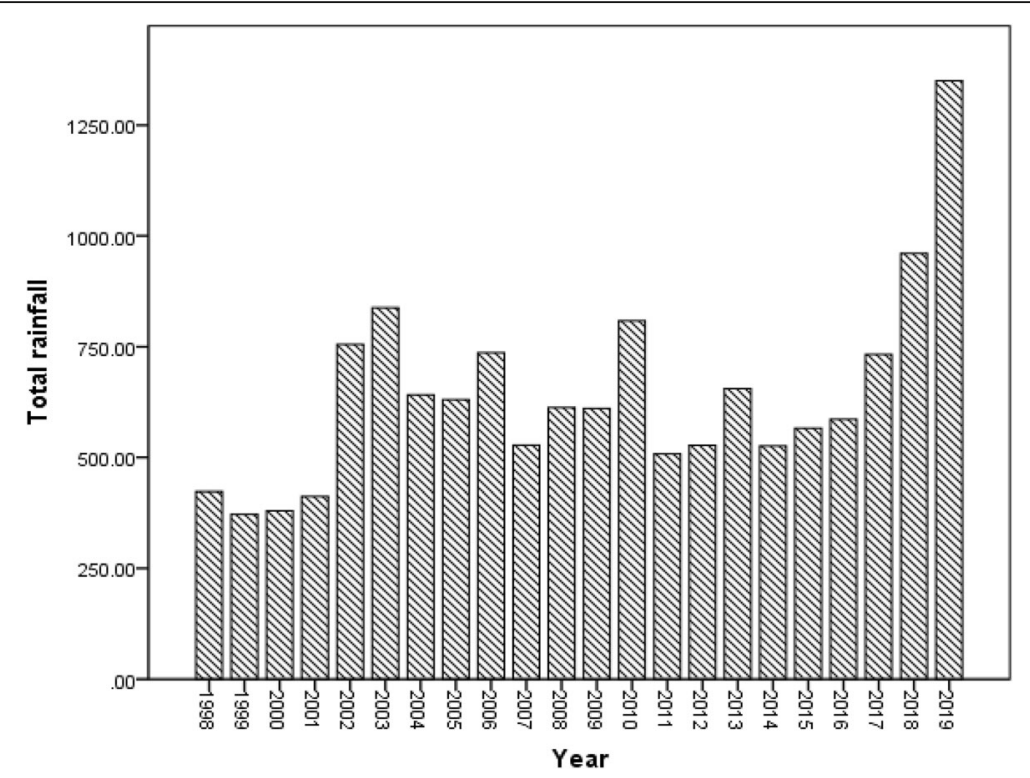

Fig. 3 Annual rainfalls from 1998 to 2019 in the study district

one of the study years. The average annual rainfall was about $643.6 \mathrm{~mm}$ (Fig. 3).

The mean annual temperature of the study area varies from 19.1 to $20.7^{\circ} \mathrm{C}$ with $20.2^{\circ} \mathrm{C}$ as the long-term average temperature of the region. The maximum temperatures ranged from 25.6 to $27.9^{\circ} \mathrm{C}$ and the minimum from 10.8 to $15^{\circ} \mathrm{C}$. Average temperatures of the study years were also 19.1 and $19.8^{\circ} \mathrm{C}$ in 2018 and 2019, respectively. In general, December to February is the hot dry season, March to May the main rainy season, while June to August the cold dry season and the period September to November the small rainy season (Fig. 4).

\section{Vegetation}

The Borana plateau is dominated by Savanna type of vegetation containing a mixture of perennial herbaceous and woody plants (Desta and Coppock 2004). However, significant vegetation changes in the form of bush encroachment have taken place in Har-Weyu communal grazing area and the Dida-Tuyura government ranch. The current vegetation of the study sites consisted mainly of closed woodland (bush land cover) with poor herbaceous cover. According to the opinion of elder pastoralists and ranch workers, no burning of the grazing areas took place after the

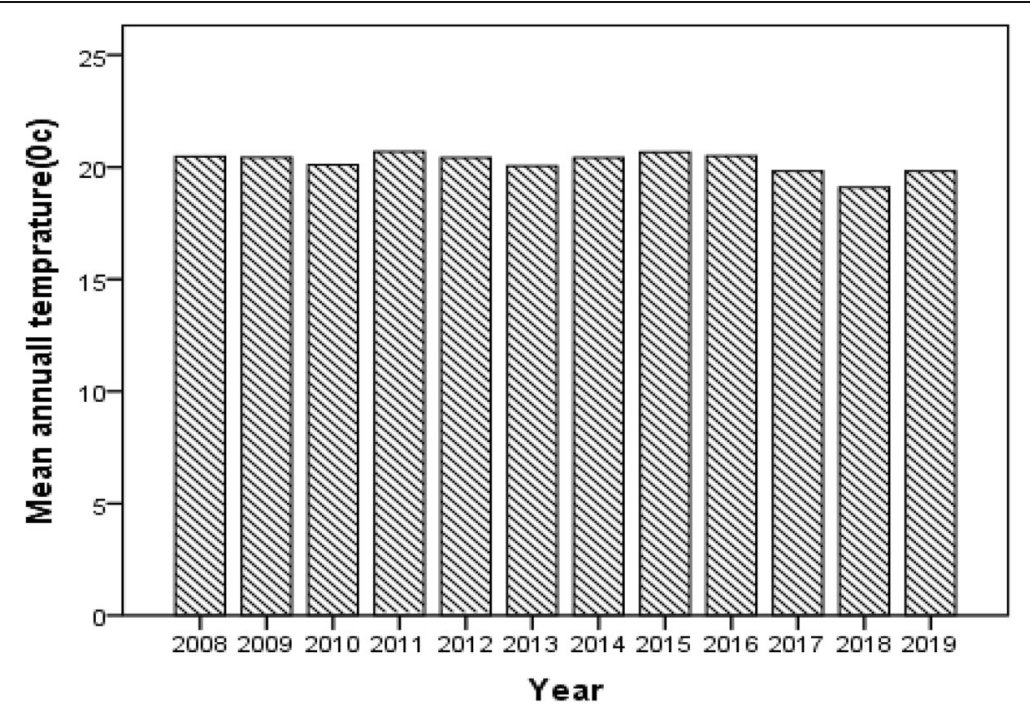

Fig. 4 Mean annual temperatures recorded (2008-2019) at the region weather station (source: data from the National Meteorological Service Agency of Ethiopia) 
official ban on fire in 1970s. Before the present day's dense woody cover and prior to the ban onuse of fire, the pastoral community periodically conducted range burning in the dry season. The encroachment of woody plants, particularly acacia species, resulted in severe degradation of the grazing lands and threatened the livestock-based production and livelihood system of the community.

\section{Field layout}

A 3 ha of land encroached by woody species was divided into two plots. Each replication with an area of $300 \mathrm{~m} \times$ $50 \mathrm{~m}$ was again sub-divided into six plots (each with 50 $\mathrm{m} \times 50 \mathrm{~m}$ ) to accommodate six treatments: namely control (CO), refers to untreated plot representing bushencroached range site; cutting $(C)$, refers to chopping down trees; cutting and browsing $(\mathrm{C}+\mathrm{B})$, refers to allowing herbivores to remove the freshly growing stump buds following tree cutting; cutting and fire $(\mathrm{C}+\mathrm{F})$, refers to chopping and immediate burning of tree stumps; cutting and fire-browse combination $(\mathrm{C}+\mathrm{F}+\mathrm{B})$, refers to chopping and stump burning followed by browsing; and stem-burning (SB), refers to treating the basal area of trees using fire. Treatments were assigned randomly to the plots and replicated two times within plots across the study sites. A border of $10 \mathrm{~m}$ was established to minimize edge effects.

During the pre-treatment activities, all woody individuals $>0.5 \mathrm{~m}$ height in each plot were counted and their species recorded. Woody plants in the $\mathrm{C}, \mathrm{C}+\mathrm{B}, \mathrm{C}+\mathrm{F}$ and $\mathrm{C}+\mathrm{F}+\mathrm{B}$ plots were thinned by cutting, whereas in the $\mathrm{SB}$, plot thinning was executed using fire (localized). The intensity of thinning was $60 \%$ of the tree density of the individual treatment plots. The decision on the intensity of thinning was based on the relatively few research activities undertaken in the Borana rangelands. For example, Allen (2000) had left 20-50 large trees perhaps to re-establish the savanna in the Borana ecology while undertaking his research. (Abule E: Rangeland suitability evaluation for livestock production in Laga-Wata/Laga Sura, Dawa and rift valley basins of the Borana Zone of Oromia, Southern Ethiopia, unpublished) undertook a study on the effect of different intensities of thinning (35-100\%) Acacia mellifera trees on grass production. Similarly, (Getachew G, Dirriba N, Abule I: Effect of fvon bush invasion in South Ethiopia 1: The Case of Dikale and Dambi pastoral associations, Borana, unpublished) undertook research on the effect of silvicultural thinning and prescribed burning on bush invasion in Dikale and Dambi pastoral associations where the intensity of thinning was $60 \%$. During thinning, trees were randomly marked, sawn off at the ground level and were removed from the plot. A fairly even spread of the remaining trees was ensured without favouring a particular tree size and species. The resultant thinned plots resembled the structure of naturally occurring open stands of woody plants in savanna (Smit 2005). The control (CO) plot (referred to as unthinned plot) was characterized by dense stands of encroaching woody species and used as a benchmark against which other control methods could be evaluated.

For the two burning treatments (i.e. $\mathrm{C}+\mathrm{F}$ and $\mathrm{C}+\mathrm{F}+\mathrm{B}$ ), dry woody branches were collected prior to burning, chopped into finer pieces and piled on top of stumps to create a fine fuel load for burning (Ayana and Oba 2009). Tree stumps in the cutting (C) treatment plot were left untreated. In the stem-burning (SB) plot, randomly selected trees were treated with fire at the base of the stem by packing the basal area with enough dry vegetation to create fuel loads (Donaldson 1966; De Klerk 2004).

Browsing treatments $(\mathrm{C}+\mathrm{B}$ and $\mathrm{C}+\mathrm{F}+\mathrm{B})$ were conducted using goats at a high stocking rate (Smit et al. 1999). Allen (2000) recommends grazing an area heavily with goats before the thorn on the re-sprout has had a chance to harden. In order to achieve a greater impact on stumps, 30 head of goats $\mathrm{ha}^{-1}$ were herded in the plots for 2 weeks and repeated six times between 2018 and 2019. This stocking rate was not based on objective assessment of the available browse, but was intended to impact coppicing as severely as possible. Browsing was regularly 2 weeks after the onset of seasonal rains or showers intended to allow possible coppicing of cut stumps. Fencing was used as a protection from unscheduled and other external disturbances, while the control plot was excluded from all disturbances.

\section{Sampling method}

Cutting and burning treatments were completed in February 2018. Browsing was first applied in March 2018 following the main season's rain. During the posttreatment activities, the following were monitored: tree mortality (complete or partial) for the control plot, whereas for the treatment plots monitoring was for stump total kill, i.e. complete mortality $(\mathrm{M})$ of the stumps under observation due to treatment effect; partial mortality (PM), refering to partial damage to the stump due to treatment effect; coppicing $(C)$, refering to re-growth in response to treatment effect (Ayana and Oba 2009). Mortality was determined from the examination of the wood beneath the bark. Individual woody plants were classified dead when all stems had succumbed, partial if partially damaged and survived when coppiced (Mathembekaya 2000).

\section{Analysis***}

Descriptive statistics were used to summarize responses of individual species in terms of plant mortality (number of 
Table 1 Response percentages of individual woody species in terms of complete mortality (M), partial mortality (PM) and coppicing (C) for six bush control treatments in the Borana rangelands

\begin{tabular}{|c|c|c|c|c|c|c|c|c|c|c|c|c|c|c|c|c|c|c|}
\hline \multirow[b]{3}{*}{ Species list } & \multicolumn{18}{|c|}{ Bush control methods } \\
\hline & \multicolumn{3}{|c|}{$\mathrm{CO}$} & \multicolumn{3}{|l|}{ C } & \multicolumn{3}{|c|}{$\mathrm{C}+\mathrm{B}$} & \multicolumn{3}{|l|}{$\mathrm{C}+\mathrm{F}$} & \multicolumn{3}{|c|}{$\mathrm{C}+\mathrm{F}+\mathrm{B}$} & \multicolumn{3}{|l|}{ SB } \\
\hline & $M$ & PM & $C$ & M & PM & $C$ & $M$ & PM & $C$ & $M$ & PM & C & $M$ & PM & $C$ & M & PM & $C^{*}$ \\
\hline A. mellifera & 3.5 & 0.7 & NM & 40.4 & 0.7 & 58.9 & 70 & 2 & 28 & 90 & 0 & 10 & 95 & 1 & 4 & 98.8 & 0 & 1.2 \\
\hline A. drepanolobium & 5.4 & 0.6 & NM & 45.4 & 0.2 & 54.4 & 79 & 0.5 & 20.5 & 66.7 & 0 & 33.3 & 94 & 1 & 5 & 98 & 0 & 2 \\
\hline A. reficiens & 2.7 & 0.5 & NM & 79.1 & 1.5 & 19.4 & 91 & 0 & 9 & 85.8 & 0 & 14.2 & 96.1 & 0 & 3.9 & 98.8 & 1 & 1.2 \\
\hline Mean proportion (\%) & 3.9 & 0.6 & NM & 55 & 0.8 & 44.2 & 80 & 0.8 & 19.2 & 80.8 & 0 & 19.2 & 95 & 0.7 & 4.3 & 98.5 & 0.3 & 1.5 \\
\hline
\end{tabular}

$C O$ control, $C$ cutting, $C+B$ cutting and browsing, $C+F$ cutting and fire, $C+F+B$ cutting combined to fire and browsing, $S B$ stem-burning, $M$ mortality, $P M$ partial mortality, $C^{*}$ coppicing, NM not measured

individuals killed/number of pre-treatment individuals for the species $\times 100$ ), partial mortality (number of partially killed individuals/number of pre-treatment individuals for the species $\times 100$ ) and percent of coppicing (number of individuals coppicing post-treatment/number of pretreatment individuals for the species $\times 100$ ) (Ayana and Oba 2009). Data was analysed using $R$ software (R Development Core Team 2005) and Tukey's HSD (Honestly Significant Difference) for post hoc multiple test for mean comparison. Differences were considered significant at $P<0.05$.

\section{Result}

\section{Effects of different treatments on woody plants}

Table 1 provides response percentages of individual woody species to different bush control treatments. The finding showed that there was a significant $(P<0.05)$ difference in the mean proportions (\%) of stump coppicing among the five stump control treatments. A larger population of coppicing stumps was recorded in the cutting (44.2\%) than in the other four treatments (i.e. SB, $\mathrm{C}+\mathrm{F}+\mathrm{B}, \mathrm{C}+\mathrm{B}$ and $\mathrm{C}+\mathrm{F})$. There was also a significant difference $(P<0.05)$ in the mean proportions of complete mortality among the six bush control methods. More proportion of dead plants were observed in stemburning (SB) than in the other study treatments (Fig. 5).

On the other hand, bush control treatments were insignificant $(P>0.05)$ in terms of partial kill of woody plants (Table 1).

Even though there was no statistically significant difference $(P>0.05)$ between $\mathrm{SB}(98.5 \%)$ and $\mathrm{C}+\mathrm{F}+\mathrm{B}$ (95.1\%), SB treatment was more effective in killing plant species. According to the current study, $\mathrm{C}+\mathrm{F}+\mathrm{B}$ ranked as the second best option of controlling species coppicing. Though insignificantly $(P>0.05)$ different, percentage dead stumps due to $\mathrm{C}+\mathrm{F}(80.8 \%)$ and $\mathrm{C}+\mathrm{B}$

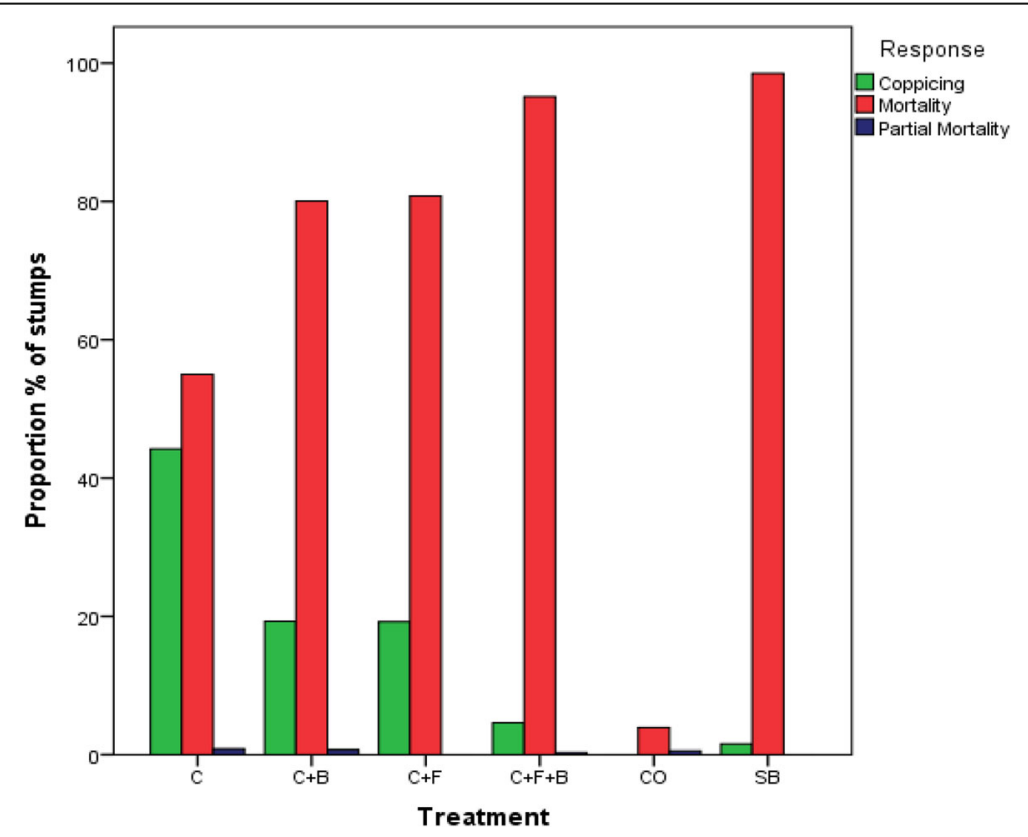

Fig. 5 Mean proportions (\%) of coppicing and mortalities among six bush control treatments 
(80\%) were high. Therefore, $\mathrm{C}+\mathrm{F}$ and $\mathrm{C}+\mathrm{B}$ were placed as the third alternative options in controlling resprouting of woody plants. Cutting $(55 \%)$ greatly $(P<$ $0.05)$ increased plant mortality compared to the control (CO) treatment. However, cutting promoted stump coppicing $(44.2 \%)$ relative to the results achieved by $\mathrm{SB}, \mathrm{C}+\mathrm{F}+\mathrm{B}, \mathrm{C}+\mathrm{F}$ and $\mathrm{C}+\mathrm{B}$ treatments, thus positioned as the last option in controlling coppicing of woody plant species. In the control $(\mathrm{CO})$ plot, percentage mortality (3.9\%) of woody plants was generally low, showing that survival of the majority of encroaching species was ensured in the control than in the other five treatments. In addition, it was observed during the experiment that fresh young shoots grow from old and dying trees as a replacement (Fig. 5).

\section{Interactive effect of treatments}

There was an interaction among treatments $(P<0.05)$ on plant mortality, indicating the presence of variability among bush control treatments in terms of killing woody plants. Overall, stem-burning (SB) was significant $(P<0.05)$ in killing encroaching woody plant species.

\section{Species response to treatments}

Responses of individual woody species due to treatments differed significantly $(P<0.05)$ in terms of die-off and survival. The result showed that mean percentage dead A. mellifera $(98.8 \%)$ was significantly $(P<0.05)$ higher for SB compared to the other five treatments. Accordingly, stem-burning was ranked first in killing $A$. mellifera. Though there was no significant difference $(P>0.05)$ between $\mathrm{C}+\mathrm{F}+\mathrm{B}(95 \%)$ and $\mathrm{C}+\mathrm{F}(90 \%)$, the $\mathrm{C}+\mathrm{F}+\mathrm{B}$ method was more effective in controlling coppicing of A. mellifera trees. According to the current findings, $\mathrm{C}+\mathrm{F}$ was ranked as the third most effective method, while $\mathrm{C}+\mathrm{B}(70 \%)$ placed as the fourth alternative option of controlling re-sprouting of $A$. mellifera. On the other hand, percentage coppicing (58.9\%) of A. mellifera due to cutting $(C)$ treatment was higher $(P<0.05)$ compared to the other four treatments. It was observed during the experiment that cut stumps of A. mellifera produced 4-6 new shoots, showing that cutting $(C)$ was not as effective as $\mathrm{SB}, \mathrm{C}+\mathrm{F}+\mathrm{B}, \mathrm{C}+\mathrm{B}$ and $\mathrm{C}+\mathrm{F}$ treatments in controlling coppicing of $A$. mellifera.

The difference between SB (98.8\%) and C+F+B (96.1\%) was statistically insignificant $(P>0.05)$ in terms of killing A. reficiens. Hence, the two treatments (i.e. $\mathrm{SB}$ and $\mathrm{C}+\mathrm{F}+\mathrm{B}$ ) were considered as the first best options in limiting the encroachment of $A$. reficiens trees. Even though there was no significant $(P>0.05)$ difference among $\mathrm{C}+\mathrm{B}$ (91\%), $\mathrm{C}+\mathrm{F}(85.8 \%)$ and $\mathrm{C}(79.1 \%)$ treatments, $\mathrm{C}+\mathrm{B}$ was more effective in killing stumps of $A$. reficiens. According to the current finding, $\mathrm{C}+\mathrm{B}$ was ranked as the second best option in controlling thickening of $A$. reficiens, whereas $\mathrm{C}+\mathrm{F}$ and $\mathrm{C}$ treatments were placed as the third and fourth alternative options, respectively. It was observed during the study that the number of new shoots in A. reficiens ranged from 1 to 2 per stump following cutting $(\mathrm{C})$ treatment which is lower relative to the number of shoots produced by the other two species due to similar treatment. Lower basal coppicing is an indication of susceptibility suggesting that cutting at the ground level is sufficient to control regeneration of $A$. reficiens.

With regard to the responses of $A$. drepanolobium, the mean percentage dead for SB $(98 \%)$ was higher $(P<0.05)$ compared to the other five treatments, therefore considered as the first best option in suppressing encroachment of $A$. drepanolobium. Although the difference between $\mathrm{C}+\mathrm{F}+\mathrm{B}(94 \%)$ and $\mathrm{C}+\mathrm{B}(79 \%)$ was statistically insignificant $(P>0.05), \mathrm{C}+\mathrm{F}+\mathrm{B}$ was more effective in killing $A$. drepanolobium. According to the current finding, $\mathrm{C}+\mathrm{F}+\mathrm{B}$ and $\mathrm{C}+\mathrm{B}$ were ranked as the second and third options, respectively, while $\mathrm{C}+\mathrm{F}(66.7 \%)$ was placed as the fourth alternative method of controlling the expansion of A. drepanolobium trees. However, percentage coppicing (54.4\%) of A. drepanolobium was higher $(P<$ 0.05 ) in the cutting $(\mathrm{C})$ compared to $\mathrm{SB}, \mathrm{C}+\mathrm{F}+\mathrm{B}, \mathrm{C}+\mathrm{B}$ and $\mathrm{C}+\mathrm{F}$ treatments. Stumps of $A$. drepanolobium were observed producing 3-6 new shoots following cutting, indicating that cutting alone is not sufficient to stop A. drepanolobium from thickening.

By comparison, the mean percentage mortality for $A$. reficiens $(75.58 \%)$ was higher $(P<0.05)$ compared to the percentages for the other two species, i.e. A. mellifera (66.28\%) and A. drepanolobium (64.81\%), evidencing that $A$. reficiens was highly susceptible to the applied treatments.

\section{Discussion}

The main objective of the current study was to investigate the effect of selective cutting/thinning and followup measures on encroaching woody species. Thinning was the same for all treatments except the control. The result showed that the majority of woody species survived environmental stresses under the control $(\mathrm{CO})$ plot, while experiencing lowest mortality rate attributed to natural thinning, probably due to age-related life history, drought and pest damage. It was observed during the study that, once established, trees would not want to vacate their space and those that tend to coppice with age have the advantage of being able to produce fresh young growth to replace old and decaying woody tissue and so also keep their space in the community. These are the species that are associated with bush encroachment, indicating that encroachment would not be reversed under such protective conditions. Rather, through 
new growths and copious seed production, woody species will continue to thicken and expand (Ayana and Oba 2009). In the Borana rangelands, the evidence (e.g. Dalle et al. 2006; Abule E: Rangeland suitability evaluation for livestock production in Laga-Wata/Laga Sura, Dawa and rift valley basins of the Borana Zone of Oromia, Southern Ethiopia, unpublished) showed that between 2006 and 2009 bush cover probably increased by $11 \%$. The most clear message is that more rangelands than decades ago have experienced bush encroachment (Ayana and Oba 2009).

Mechanical cutting (C) increased woody mortality (55\%), however; relatively promoted stump coppicing (44.2\%). It was noted during the study that tree stumps produced several new shoots following cutting depending on the withstanding capacity of individual species. Stumps can produce shoots from adventitious buds that remained hidden beneath the bark, indicating that trees are capable of coppicing following cutting practice. Because coppiced stumps already have a well-developed root system, they readily re-grow. There seems a clear advantage for coppicing because if trees are cut, then they can re-sprout and maintain their space in a highly competitive environment. This finding is in accordance with Kahumba (2010) who reported that mechanical or manual control by chopping down woody plants temporarily creates open canopies without necessarily reducing woody plant densities ha ${ }^{-1}$. Unless hot fire and/or browsing are applied on stumps, coppicing will occur. Similarly, (Lubbe L: Notes on trees and shrubs in arid and semi-arid regions, unpublished) reported that most acacia species have the ability to coppice vigorously and if allowed to re-grow, various woody species will create an even denser thicket which is worse than before.

Stump mortality in response to cutting and browsing $(\mathrm{C}+\mathrm{B})$ was higher compared to the control and cutting treatments, mainly attributed to the effect of browsing preference of the fresh growing buds by goats. This finding is consistent with Smit et al. (1999) and De Klerk (2004) who reported that, as an after-care measure, goats can be introduced successfully to utilize and control regrowth as a follow-up to other methods like felling and can be effective in preventing coppicing of woody plants. According to Trollope (1974) and Van Rooyen (2016), browsing is the single most important post-treatment tool to prevent re-encroachment, because the browsers remove top coppice growth. The reduction in the overall coppicing of woody species under cutting and browsing treatment suggests the introduction of browsing animals as effective long-term management measure in the control of bush encroachment.

Tree mortality in response to cutting and fire $(\mathrm{C}+\mathrm{F})$ was greater $(P<0.05)$ compared to the control and cutting treatments, largely due to fire effect following cutting. High percentage mortality due to fire reflects that woody species response is probably determined by the duration and intensity of fire. According to the current finding, the sensitivity of $A$. reficiens and A. mellifera to $\mathrm{C}+\mathrm{F}$ treatment in terms of stump deaths suggests that the combined effect of cutting and fire was effective in the control of encroaching woody plants. This finding corresponds to Smit (2004) and Van Rooyen (2016) who reported that fire is an effective follow-up treatment, controlling the re-growth of the woody vegetation layer. A similar result was also reported by Ruthven et al. (2003) who suggested post-fire decline in many woody species. Thus, the introduction of selective cutting/thinning and fire (localized) would probably maintain the savanna ecosystems of Borana as opposed to bush clearing (radical) strategy and exclusion of fire that promoted bush encroachment.

Highly increased stump deaths were observed in woody species in response to tree cutting and firebrowse combination possibly attributed to the increased intensity of treatments. This finding is in agreement with Sawadogo et al. (2002) who reported that preferences of grazing towards individual species in terms of increased palatability and accessibility of the edible portions probably increased mortality among coppicing woody species. Similarly, Van der Waal et al. (2011) reported that herbivory in savannas is important in complementing other natural processes to maintain the tree-grass balance. Preferential utilization of woody plants by browsers (Staver et al. 2009) may help maintain grassland and savanna communities. Stump deaths in response to multiple disturbances may suggest that changes in management strategy with a combination of disturbances could greatly reduce the woody populations (Fulbright 1996). The severity of the disturbance generally results in longterm reduction in the density of woody species (Nolte et al. 1994; Ruthven et al. 2003). From the results, it is suggested that tree cutting with fire-browse combination would probably be greatly efficient in sustaining the tree-grass balance ratio in savanna ecosystem than a single cutting/clearing method practised so far.

Total stump mortality in response to stem-burning (SB) treatment was the highest compared to the other five treatments. A drop in the amount of coppicing was observed in all tree species treated with fire. The sensitivity to treatment in terms of stump kills suggests that the effect of stem-burning treatment was highly effective in the control of stump coppicing in the long term. The level of damage might be related to lower burning height and duration and intensity of fire. It was observed that stem-burning is most effective if done as near to the ground level as possible. This finding is in accordance with Dreber et al. (2019) who reported that stemburning is effective in controlling coppicing of $S$. 
mellifera where almost all the population showed no coppicing following the application of the treatment. Similarly, De Klerk (2004) reported that stem-burning of $A$. mellifera tree close to the ground level is very effective. Thus, stem-burning can be considered as an alternative to manual bush control which promotes coppicing of woody species. The technique seems relatively safe if applied when grass has been removed or grazed. The method also presents an alternative to the use of range fires.

In the cutting (C) treatments, woody species were thinned by cutting at the ground level which probably promoted stump coppicing which is an inherent property of encroaching woody plants. Earlier studies (e.g. Bond et al. 2001; Vesk 2006) indicated that woody species have different strategies for survival. Survival (i.e. coppicing) by woody species probably reflects the capacity of individuals to withstand damage by adapting a coppicing strategy (Vesk 2006; Ayana and Oba 2009). Woody species experienced greater coppicing in response to cutting showing that the impact on bush encroachment is likely to be short term, thus reducing the effective time span of rehabilitation measures. Since the establishment of woody plants is normally a continuing process in savanna areas, control cannot be achieved with a single cutting operation (Smit et al. 1999; Smit 2004).

\section{Conclusion}

In the Borana rangelands, there is a substantial decline in production and carrying capacity of rangeland as a result of bush encroachment. The purpose of this study was to investigate the effects of selective cutting/thinning and after-care treatments on encroaching woody plants. The widespread use of combinations of methods would serve to sustain a grassland savanna. The findings showed that five out of the six bush control treatments greatly increased tree mortality, however with speciesspecific differences. The stem-burning, tree cutting with fire-browse combination, cutting and fire, cutting and browsing, and cutting treatments greatly increased species mortality compared to the control treatment. The significant finding is that woody plants showed high mortality rates in response to selective cutting/thinning and followup treatments. Thinning and post-management measures would sustain savanna ecosystems, improve rangeland condition and pastoral livelihoods, if implemented at certain intervals.

\section{Recommendation}

Rangelands serve as the main feed base for livestock and a centre of livelihood for Boran pastoralists. However, encroachment of woody plants is impeding rangeland resource management and threatening pastoral livelihoods.
The following points are recommended to restore bushencroached rangeland:

- The extent and nature of the encroachment problem needs to be assessed together with the community in a participatory way before planning how to manage bush encroachment.

- Ecologically sound approaches need to be met in making any decision on the most appropriate procedures to manage bush encroachment.

- Management of bush encroachment must be a longterm commitment rather than a one-off event.

- Sound grazing management practices are critically important, especially during wet seasons, which will ensure a vigorous and competitive herbaceous layer.

- The management of woody vegetation in relation to the grazer animals (cattle and sheep) and that of the browsers (goats and camels) need to be considered under the Borana conditions. It is advisable to try to aim at an open savanna comprised mainly of large trees, but with at least some small trees for grazer animals. Woody species should be cut to a density that represents a grassland savanna and what the pastoralists feel are appropriate for shade and other needs. If bush control treatments are applied, care should also be taken to keep a certain proportion of trees and shrubs as fodder sources for browsing livestock. The thinning operation to be undertaken is to open up the closed vegetation for easy movement of the browsers (camels and goats) and the herders in dense vegetation types.

- In general, any bush control programme should focus on tree thinning rather than clearing of all woody plants. Thinning practices should integrate follow-up measures to sustain savanna ecology. In making decisions on the intensity of tree thinning, what size of the trees should be removed, and what species to be thinned, cognizance should thus be taken of the importance of achieving a balanced compromise between reduction of the competitive effect of trees on the herbaceous layer versus preservation of the positive influence which trees may have on the system (Smit 2004).

- Most importantly, the Federal Democratic Republic of Ethiopia should boost a policy environment conducive to resolving the problems that pastoralists face with bush encroachment. As far as these problems are concerned, the Government should commit itself to direct involvement and support to the pastoral sector in filling certain shortcomings in policies and legislation which need some attention. This includes formulation of a policy to manage rangelands, which needs to be seen as an urgent priority. In this regard, bush thinning and post- 
management measures as long-term management strategy should be provided for. Additionally, a rangeland management policy and plan should be introduced under the Forest Proclamation No. 542/ 2007 to incorporate issues pertaining to bush lands that fall outside the current definitions of forest and areas classified as forests.

- Future study should focus on long-term effects of bush control methods for more dependable results.

- More action research should be undertaken to identify appropriate seasons for thinning different species.

- Training of the development practitioners and the communities is important to help bridge the gaps related to knowledge and concept of tree thinning for different species.

\section{Abbreviations}

M: Mortality; PM: Partial mortality; C: Coppicing; TLU: Tropical Livestock Unit; M.a.s.l: meter above sea level

\section{Acknowledgements}

We are very grateful to all pastoralists and area experts participating in this study by providing access to their rangelands and sharing their knowledge.

\section{Authors' contributions}

Malicha L. conceived and designed the study, conducted the fieldwork, analyzed the data, interpreted the findings and prepared the manuscript. Xinwen $X$. was a promoter. Abule E. acted as co-promoter and contributed in designing the work. Yongdong W., You Y. and Zhou N. all had facilitation and technical roles throughout the process. All the authors read and approved the manuscript.

\section{Funding}

This study received financial support from the African Great Green Wall Adaptation Technical Cooperation Research and Demonstration (2018YFE0106000); Science and Technology Partnership Program, Ministry of Science and Technology of China (Grant No. KY 201702010); and International cooperation and Exchanges NSFC (Grant No. 41861144020).

\section{Availability of data and materials}

Not applicable.

\section{Ethics approval and consent to participate}

Not applicable.

\section{Consent for publication}

Not applicable.

\section{Competing interests}

The authors declare that they have no competing interests.

\section{Author details}

${ }^{1}$ State Key Laboratory of Desert and Oasis Ecology, Xinjiang Institute of Ecology and Geography, Chinese Academy of Science, Urumqi P.O. 830011 China. ${ }^{2}$ National Engineering Technology Research Centre for Desert-Oasis Ecological Construction, Beijing 100049, China. ${ }^{3}$ University of Chinese Academy of Sciences, Beijing 100049, China. ${ }^{4}$ Research and Innovation Department, Wageningen University and Research (SNV-International), Finfine, Ethiopia.

Received: 6 January 2020 Accepted: 28 April 2020

Published online: 30 July 2020

\section{References}

Allen, G.R. 2000. Restoration of grazing lands in the Liben Woreda. Borana. Utah State University. American grasslands. Journal of Environmental Management 90: 2931-2942.
Ansley, R.J., and M.J. Castellano. 2006. Strategies for savanna restoration in the southern Great Plains: Effects of fire and herbicides. Restoration Ecology 14: 420-428.

Ayana, A. 2007. The dynamics of savanna ecosystem and management in Borana, South Ethiopia. Ph.D. Thesis, 183. Norway: Norwegian University of Life Sciences (UMB).

Ayana, and Oba. 2008a. Herder perceptions on impacts of range enclosures, crop farming, fire ban and bush encroachment on the rangelands of Borana, Southern Ethiopia. Human Ecology 136: 201-215.

Ayana, and Oba. 2008b. Effects of management and time on mechanisms of bush encroachment in southern Ethiopia. African Journal of Ecology 46: 186-196.

Ayana, and Oba. 2009. Bush encroachment control demonstrations in southern Ethiopia: 1. Woody species survival strategies with implications for herder land management. African Journal of Ecology 47: 63-76.

Aynalem, H., A. Workneh, K. Noah, D. Tadelle, and T. Azage. 2011. Breeding strategy to improve Ethiopian Boran cattle for meat and milk production, IPMS (Improving Productivity and Market Success) of Ethiopian Farmers Project Working Paper 26. Nairobi: ILRI.

Bond, W.J., K.A. Smythe, and D.A. Balfour. 2001. Acacia species turnover in space and time in an African savanna. Journal of Biogeography Science 28: 117-128.

Britz, M.L., and D. Ward. 2007a. Dynamics of woody vegetation in a semi-arid savanna, with a focus on bush encroachment. African Journal of Range and Forage Science 24: 131-140.

Britz, M.L., and D. Ward. 2007b. The effects of soil condition and grazing strategy on plant species composition in a semi-arid savanna. African Journal of Range and Forage Science 24: 51-61.

Brown, J.R., and S. Archer. 1999. Shrub invasion of grassland: Recruitment is continuous and not regulated by herbaceous biomass or density. Ecology 80: 2385-2396.

Buitenwerf, R., W.J. Bond, N. Stevens, and W.S.W. Trollope. 2012. Increased tree densities in South African savannas: $>50$ years of data suggests $\mathrm{CO}_{2}$ as a driver. Global Change Biology 18: 675-684 https://doi.org/10.1111/j.1365-2486. 2011.02561.x.

Central Statistical Authority (CSA). 2017. Human population statistics, Addis Ababa, Ethiopia.

Clark, D.L., and M.V. Wilson. 2001. Fire, mowing and hand removal of woody species in restoring a native wetland prairie in the Willamette Valley of Oregon. Wetlands 21: 135-144.

Coppock, D.L. 1994. The Borana plateau of southern Ethiopia: Synthesis of pastoral research development and changes, 1980-90. Addis Ababa: ILCA (International Livestock Centre for Africa).

Coppock, D.L., G. Gebru, S. Mesele, and S. Desta. 2008. 'Are drought-related crashes in pastoral cattle herds predictable? More evidence of equilibrium dynamics from southern Ethiopian rangelands', page 1090, in the organizing committee of the 2008 International Grasslands Congress/International Rangelands Congress (IGC/RC) (ed.), Multifunctional grasslands in a changing world. Vol. II, 1-154. Beijing: Guagdong People's Publishing House.

Dalle, Gemedo, B.L. Maass, and J. Isselstein. 2006. Encroachment of woody plants and its impact on pastoral livestock production in the Borana lowlands, southern Oromia, Ethiopia. African Journal of Ecology 44: 237-246.

De Klerk, J.N. 2004. Bush encroachment in Namibia. Report on phase 1 of the bush encroachment research, monitoring and management project. Windhoek: Ministry of Environment and Tourism Archive http://namibia.leadr.msu.edu/ items/show/356. Accessed 14 July 2018.

Desta, S., and D.L. Coppock. 2004. Pastoralism under pressure: Tracking system change in southern Ethiopia. Journal of Human Ecology 32: 4.

Development Core Team, R. 2005. A language and environment for statistical computing. Foundation for Statistical Computing, Vienna, Austria. Revisited Insights from an examination of assumptions and mechanisms invoked in existing models. Ecology Letters 7: 480-490.

DiTomaso, J.M., M.L. Brooks, E.B. Allen, R. Minnich, P.M. Rice, and G.B. Kyser. 2006. Control of invasive weeds with prescribed burning. Weed Technology 20: 535-548 https://doi.org/10.1007/s11258-005-9039-6.

D'Odorico, P., J.D. Fuentes, W.T. Pockman, S.L. Collins, Y. He, J.S. Medeiros, S. De Wekker, and M.E. Litvak. 2010. Positive feedback between microclimate and shrub encroachment in the northern Chihuahuan desert. Ecosphere 1: 17.

Donaldson, C.H. 1966. Control of blackthorn in the Molopo area with special reference to fire. Proceedings of the Annual Congress of the Grassland Society of Southern Africa 1 (57): 62. 
Dreber, N., S.E. van Rooyen, and K. Kellner. 2019. One savanna, many shapes: How bush control affects the woody layer in the southern Kalahari. South African Journal of Botany 125: 511-520.

Eldridge, D.J., M.A. Bowker, F.T. Maestre, E. Roger, J.F. Reynolds, and W.G. Whitford. 2011. Impacts of shrub encroachment on ecosystem structure and functioning: Towards a global synthesis. Ecology Letters 14: 709-722.

Forrest, Brigham W., et al. 2015. Economic analysis of land and livestock management interventions to improve resilience of a pastoral community in southern Ethiopia. Journal of African Economies 25: 233-266 https://doi.org/ 10.1093/jae/ejv021.

Fulbright, T.E. 1996. Viewpoint: A theoretical basis for planning woody plant control to maintain species diversity. Journal of Range Management 49: 554559.

Grant, W.E., W.T. Hamilton, and E. Quintanilla. 1999. Sustainability of agroecosystems in semi-arid grasslands: Simulated management of woody vegetation in the Rio Grande Plains of southern Texas and northeastern Mexico. Ecological Modelling 124: 29-42.

Helland, J. 1980. Social organization and water control among the Borana of southern Ethiopia, 30. Nairobi: Working document 16. ILCA (International Livestock Center for Africa).

Higgins, S.I., W.J. Bond, E.C. February, A. Bronn, D.I.W. Euston-Brown, B. Enslin, N. Govender, L. Rademan, S. O'Regan, A.L.F. Potgieter, S. Scheiter, R. Sowry, L. Trollope, and W.S.W. Trollope. 2007. Effects of four decades of fire manipulation on woody vegetation structure in savanna. Ecology 88: 1119-1125.

Hoffman, T., and A. Ashwell. 2001. Nature divided: Land degradation in South Africa. Cape Town: University of Cape Town Press Accessed 9 Apr 2020.

Kahi, C.H., R.K. Ngugi, S.M. Mureithi, and J.C. Ng'ethe. 2009. The canopy effects of Prosopis juliflora (DC.) and Acacia tortilis (Hayne) trees on herbaceous plants species and soil physio-chemical properties in Njemps flats, Kenya. Tropical and Subtropical Agroecosystems 10: 441-449.

Kahumba, A. 2010. Comparison of the rehabilitative effects of mechanical and chemical methods of bush control on degraded highland and savanna rangelands in Namibia. M.Sc. Thesis. Namibia: University of Namibia Archive http://repository.unam.edu.na/handle/11070/507. Accessed 21 May 2019.

Kamara, A., B. Swallow, and M. Kirk. 2002. Role of policies and development interventions in pastoral resource management: The Borana rangelandss in southern Ethiopia. Socio-economics and policy research working paper 35, 42 Nairobi: ILRI (International Livestock Research Institute).

Keba. 2013. The impact of changes in land-use and rainfall variability on range condition and pastoral livelihoods in the Borana rangelands of southern Oromia, Ethiopia, Thesis submitted in the partial fulfillment of the requirements for the degree Doctor of Philosophy in pasture science. University of Pretoria, South Africa Available at: https://repository.up.ac.za/ bitstream/handle/2263/32981. Accessed 16 Apr 2019.

Kulmatiski, A., and K.H. Beard. 2013. Woody plant encroachment facilitated by increased precipitation intensity. Nature Climate Change 3: 833-837.

Lesoli, M.S., M. Gxasheka, T.B. Solomon, and B. Moyo. 2013. Integrated plant invasion and bush encroachment management on Southern African rangelands management. Available at: https://www.intechopen.com/book. Accessed 15 Feb 2018.

Masters, R.A., and R.L. Sheley. 2001. Principles and practices for managing rangeland invasive plants. Journal of Range Management 54: 502-517.

Mathembekaya M. 2000. Soil, herbaceous and woody responses to different methods of bush control in a mesic Eastern Cape savanna. Thesis submitted in partial fulfilment of the requirements for the degree Master of Science in Range and Forage Resources, School of Applied Environmental Sciences, Faculty of Science and Agriculture, University of Natal. Available at: https://researchspace.ukzn.ac.za/handle/10413/5090. Accessed 11 Apr 2019

Megersa, B., A. Markemann, A. Angassa, and Zarate A. Valle. 2014. The role of livestock diversification in ensuring household food security under a changing climate in Borana, Ethiopia. Food Security 6: 15-28.

Miller, R.W., and R.L. Donahue. 1995. Soils in our environment. 7th ed, 649. London: Prentice Hall.

Nolte, K.R., T.M. Gabor, M.W. Hehman, M.A. Asleson, T.E. Fulbright, and J.C. Rutledge. 1994. Long term effects of brush management on vegetation diversity in ephemeral drainages. Journal of Range Management 47: 457-459.

O'Connor, T.G., J.R. Puttick, and M.T. Hoffman. 2014. Bush encroachment in southern Africa: Changes and causes. African Journal of Range and Forage Science 31: 67-88 https://doi.org/10.2989/10220119.2014.939996.

Oba, G. 1998. Assessment of indigenous range management of the Borana pastoralists of southern Ethiopia. In GTZ: Borana lowland pastoral development program Available at: https://pdfs.semanticscholar.org/50e1/75 f0378501f8da98a5a8f0dc568acc65f652. Accessed 5 June 2018.

Oba, G., E. Post, P.O. Syvertsen, and N.C. Stenseth. 2000. Bush cover and range condition assessments in relation to landscape and grazing in southern Ethiopia. Landscape Ecology 15: 535-546.

Olson, R.A., and T.D. Whitson. 2002. Restoring structure in late-successional sagebrush communities by thinning with tebuthiuron. Restoration Ecology 10 146-155.

Pienaar, F.C. 2006. A plant ecological evaluation of mechanical bush thinning in Marekele Park, Limpopo Province. M.Sc. Thesis, Bloemfontain, Department of Animal, Wildlife and Grassland Sciences, UVS, Bloemfontein. 296. Free-State University. Available at: https://pdfs.semanticscholar.org. Accessed 10 Sept 2019.

Pienaar, G. 2008. The inclusivity of communal land tenure: A redefinition of ownership I Canada and South Africa? Stellenbosch Law Review 19: 259-277 Available at: https://www.ejcl.org/121/art121-19.pdf. Accessed 14 Sept 2019.

Pratt, D.J., and M.D. Gwynne. 1977. Range management and ecology in East Africa. London: Hodder and Stoughton.

Riginos, C., J.B. Grace, D.J. Augustine, and T.P. Young. 2009. Local versus landscape-scale effects of savanna trees on grasses. Journal of Ecology 97: 1337-1345.

Riginos, C., and T. Young. 2007. Positive and negative effects of grass, cattle and wild herbivores on acacia saplings in an East African savanna. Oecologia 153: 985-995.

Ruthven, D.C., A.W. Braden, H.J. Knutson, J.F. Gallagher, and D.R. Synatzske. 2003. Woody vegetation response to various burning regimes in South Texas. Journal of Range Management 56: 159-166.

Sankaran, M., N.P. Hanan, R.J. Scholes, J. Ratnam, D.J. Augustine, B.S. Cade, J. Gignoux, S.I. Higgins, X. Le Roux, F. Ludwig, J. Ardo, F. Banyikwa, A. Bronn, G. Bucini, K.K. Caylor, M.B. Coughenour, A. Diouf, W. Ekaya, C.J. Feral, E.C. February, P.G.H. Frost, P. Hiernaux, H. Hrabar, K.L. Metzger, H.H.T. Prins, S. Ringrose, W. Sea, J. Tews, J. Worden, and N. Zambatis. 2005. Determinants of woody cover in African savannas. Nature 438: 846-849.

Sawadogo, L., R. Nygard, and F. Pallo. 2002. Effects of livestock and prescribed fire on coppice growth after selective cutting of Sudanian savannah in Burkina Faso. Annals Forest Science 59: 185-195.

Smit, G.N. 1999. Acacias of South Africa. 1st ed, 223. Pretoria: Briza Publications.

Smit, G.N. 2005. An approach to tree thinning to structure southern African savannas for long term restoration from bush encroachment. Journal of Environmental Management 71: 179-191.

Smit, G.N., C.G.F. Ritcher, and A.J. Aucamp. 1999. Bush encroachment: An approach to understanding and managing the problem. In Veld management in South Africa, ed. N.M. Tainton. Pietermaritzburg: University of Natal Press.

Smit, I.P.J., G.P. Asner, N. Govender, T. Kennedy-Bowdoin, D.E. Knapp, and J. Jacobson. 2010. Effects of fire on woody vegetation structure in African savanna. Ecological Applications 20: 1865-1875.

Solomon, B.T., and V. Mblambo. 2010. Encroachment of Acacia brevispica and Acacia drepanolobium in semi-arid rangelands of Ethiopia and their influence on sub canopy grasses. Research Journal of Botany 5: 1-13.

Staver, C.A., W.J. Bond, W.D. Stock, S.J. van Rensburg, and M.S. Waldram. 2009 Browsing and fire interact to suppress tree density in an African savanna. Ecological Applications 19: 1909-1919.

Tache, B., and G. Oba. 2010. Is poverty driving Borana herders in southern Ethiopia to crop cultivation? Human Ecology 38: 639-649.

Tainton, N.M. 1999. Veld management in Southern Africa. Pietermaritzburg: University of Natal Press Technical paper 20. ISRIC, Wageningen, the Netherlands.

Tamene, Y. 1990. Population dynamics of the problem shrubs, Acacia drepanolobium and Acacia brevispica in the southern rangelandss of Ethiopia, M.Sc. thesis, University of New South Wales, Kensington, Australia, Department of Animal Production and Range Science, 36. BoranaLibrary Accessed Mar 2020: SORDU.

Teague, W.R. 1989a. Monitoring vegetation in thorn/grass communities. In Veld management in the Eastern Cape, ed. J.E. Danckwerts and W.R. Teague, 99102. Pretoria: Department of Agriculture and Water Supply.

Teague, W.R. 1989b. Grass/bush communities. In Veld management in the Eastern Cape, ed. J.E. Danckwerts and W.R. Teague, 155-165. Pretoria: Department of Agriculture and Water Supply.

Teshome, A., E. Abule, and N. Lisanework. 2012. Evaluation of woody vegetation in the rangeland of Southeast Ethiopia. International Research Journal of Agricultural Science and Soil Science 2: 113-126. 
Trollope, W.S.W. 1974. Role of fire in preventing bush encroachment in the Eastern Cape. Proceedings Grassland Society Southern Africa 9: 67-72.

Trollope, W.S.W. 1999a. Fire behaviour. In Veld management in South Africa, ed. N. M. Tainton. Pietermaritzburg: University of Natal Press.

Trollope, W.S.W. 1999b. Veld burning. In Veld management in South Africa, ed. N. M. Tainton.

Úbeda, X., and L. Outeiro. 2009. Physical and chemical effects of fire on soil. In Fire effect on soils and restoration strategies, ed. A. Cerdà and P.R. Robichaud, 105-133. Enfield: Science Publishers.

Van Auken. 2009. Causes and consequences of woody plant encroachment into western North American grasslands. Journal of Environmental Management 90: 2931-2942.

Van der Waal, C., A. Kool, S.S. Meijer, E. Kohi, I.M.A. Heitkonig, W.F. De Boer, F. Van Langevelde, R.C. Grant, M.J.S. Peel, R. Slotow, H.J. De Knegt, H.H.T. Prins, and H. De Kroon. 2011. Large herbivores may alter vegetation structure of semiarid savannas through soil nutrient mediation. Oecologia 65: 1095-1107.

Van Rooyen. 2016. Composition and structure of woody vegetation in thickened and controlled bushveld savanna in the Molopo, South Africa. Dissertation Magister Scientiae in Environmental Sciences at the Potchefstroom Campus of North-West University. Archive: https://pdfs.semanticscholar.org/. Accessed 27 Nov 2019.

Van Rooyen, N. 2002. Veld management in the savannas. In Game ranch management, ed. J. du P. Bothma, 4th ed., 571-620. Pretoria: Van Schaik.

Vesk, P.A. 2006. Plant size and re-sprouting ability: Trading tolerance and avoidance of damage? Journal of Ecology 94: 1027-1034.

Ward, D. 2005. Do we understand the causes of bush encroachment in African savannas? African Journal of Range and Forage Science 22: 101-105.

Ward, D., B.T. Ngairorue, J. Karamata, I. Kapofi, R. Samuels, and Y. Ofran. 2000. Effects of communal pastoralism on vegetation and soil in a semi-arid and in an arid region of Namibia. In Vegetation science in retrospect and perspective, ed. P.S. White, L. Mucina, J. Leps, and E. Van Der Maarel, 344-347. Uppsala: Opulus Press Archive https://www.google.com/search? Accessed 14 Apr 2020.

Ward, D., K. Wiegand, and S. Getzin. 2013. Walter's two-layer hypothesis revisited: back to the roots. School of Life Sciences, University of KwaZulu-Natal, P. Bas X01, Scottsville 3209, South Africa. Oecologia 172: 617-630 https://doi.org/10. 1007/s00442-012-2538-y.

Zimmermann, I., F.N. Mwazi, and P. Zensi. 2003. Application of goat pressure after fire aimed at controlling bush thickening in mountain savanna of Namibia. In Proceedings of the VIII International Rangeland Congress 26th July-7st August, Durban, South Africa, ed. N. Allsopp, A.R. Palmer, S.J. Milton, K.P. Kirkman, G.I. H. Kerley, and C.J. Brown, 981-998 Archive: https://rangelandcongress.org/ past-congresses. Accessed 18 July 2019.

\section{Publisher's Note}

Springer Nature remains neutral with regard to jurisdictional claims in published maps and institutional affiliations.

\section{Submit your manuscript to a SpringerOpen ${ }^{\circ}$ journal and benefit from:}

- Convenient online submission

- Rigorous peer review

- Open access: articles freely available online

- High visibility within the field

- Retaining the copyright to your article

Submit your next manuscript at $\boldsymbol{\nabla}$ springeropen.com 